\title{
Penetration of private places in Theodotian Susanna
}

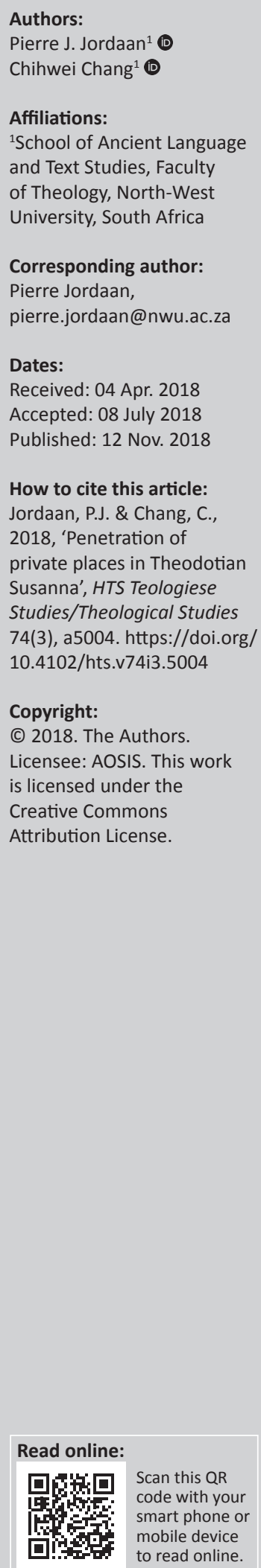

The Theodotian Susanna has been studied by various scholars in various ways. Each attempt to give some meaning to this narrative has a different emphasis from a text, context or receiver based angle. This paper presents a mixture of text and context based angles. It focuses on the different spaces in Theodotian Susanna, that is, the house, garden, court and finally heaven. Each of these spaces is contested, but there can only be one victor.

\section{Introduction and problem statement Introduction}

There has been a never-ending interest in the study of Theodotian Susanna over the past 40 years. There are various reasons for this; maybe Ingo Kottsieper was right when he stated that Susanna had everything that entices even the modern reader, namely: a beautiful woman and a sexual interest by two leaders in the community, who shamelessly abuse their position and then try to eliminate their victim by slander. Nevertheless, there were no shortages in attempts to interpret the Theodotian Susanna. Broadly speaking, four different approaches have been employed. Later I will mention exponents of each approach and show that sometimes there is even a mixture of these approaches in order to arrive at some understanding of Theodotian Susanna. These points of departure are:

1. Historical Critical and Historical Grammatical approaches, where the comparison of the LXX and Theodotian Susanna is typically found.

2. Cultural approaches, for instance, focusing on issues like the assumed underlying conflict between the Pharisees and Sadducees and also gender prejudice against women.

3. Spiritualising approaches towards Theodotian Susanna typical from ecclesiastical circles.

4. Lastly, unique literary approaches from mainly modern literary points of view, for instance, speech act theory, Semiotics and even narrative approaches.

Schematically and alphabetically, these scholars can be represented as follows in Table 1.

\section{Problem}

None of the commentaries above addressed the different spaces in Theodotian Susanna. There are only fragmented referrals to some aspects of the spaces among scholars like Ingo Kottsieper who mentions houses and gardens in the 'Exilgemeinde', as well as Erich Gruen who only talks about Joakim's house and garden and how the Jews needed to clean up their act abroad. However, there is no systematic focus on all the different spaces to be found in Theodotian Susanna like the house, garden, courts of law and even the cosmos.

There are only scattered, indirect references. The only exception might be Nolte and Jordaan (2010). This study is titled 'Susanna: A Story of Dangerous Spaces' and was published in the Journal for Semitics. This study of Nolte and Jordaan was shown in the Table 1 as a 'mixed approach'. It had elements of the Historical Critical and Grammatical approach, especially in using the prepositions 'above' and 'below' as they present themselves in the text. This was carefully blended with the Cognitive Linguistic Theory of Lakoff and Johnson. ${ }^{1}$

Lastly, cultural studies were used. More specifically, the status and place of Susanna was explored. This paper had as departure point of cognitive linguistics the human body. Using the 'up and

1.In the 1970 s and 1980s, linguists began to explore how abstract concepts may be based on metaphors for physical concepts. This study emphasises a meaningful relationship between one's mind and body, and how human cognition is shaped by embodied experience. Therefore, (3) begins with the following statements concerning the human mind: (1) the mind is inherently embodied; (2) thought it is mostly unconscious; and (3) abstract concepts are largely metaphorical. This article focuses on the first two observations to enrich the interpretation of Susanna. 
TABLE 1: Recent publication on Theodotian Susanna.

\begin{tabular}{lcccc}
\hline Reference & $\begin{array}{c}\text { Historical critical/ } \\
\text { grammatical }\end{array}$ & Cultural & Spiritualising & Literary \\
\hline Branch and Jordaan (2009) & - & - & $\mathrm{X}$ & $\mathrm{X}$ \\
Coetzer (2009) & $\mathrm{X}$ & - & - & $\mathrm{X}$ \\
DeSilva (2002) & $\mathrm{X}$ & - & $\mathrm{X}$ & - \\
Harrington (1999) & - & $\mathrm{X}$ & - & $\mathrm{X}$ \\
Jordaan 1 (2008) & $\mathrm{X}$ & $\mathrm{X}$ & - & - \\
Jordaan 2 (2009) & - & - & $\mathrm{X}$ & $\mathrm{X}$ \\
Kannonge (2009) & - & - & - & $\mathrm{X}$ \\
Kay (2004) & $\mathrm{X}$ & $\mathrm{X}$ & - & $\mathrm{X}$ \\
Kottsieper (1998) & $\mathrm{X}$ & $\mathrm{X}$ & - & - \\
Moore (1984) & $\mathrm{X}$ & - & - & - \\
Moore (1994) & $\mathrm{X}$ & $\mathrm{X}$ & - & $\mathrm{X}$ \\
Nickelsburg (2005) & $\mathrm{X}$ & - & - & \\
Nolte and Jordaan (2010) & $\mathrm{X}$ & $\mathrm{X}$ & - & $\mathrm{X}$ \\
\hline & & & & \\
\hline
\end{tabular}

down' scheme, the findings centred more on a cosmological level with heaven 'above' being good and Babylon 'below' being bad. Other spaces like the house and garden were briefly explored. However, this publication of Nolte and Jordaan still needs some focus and refinement.

Firstly, much more could be said of the spaces. Secondly, all these spaces needed some solid grammatical grounding of the Greek text. Thirdly, in terms of the narrative, progression or inhibition needed attention. This paper by myself and Chih W. Chang will address these gaps of the paper by Nolte and Jordaan. It will be done in the following way. Firstly, brief methodological considerations on spaces will be given. The focus will be on how the text presents attempts to penetrate these different spaces. Secondly, different spaces will be explored. Lastly, findings will be given. ${ }^{2}$

\section{Method of research}

Space forms one of the basic domains of human thinking in the house because, through our physical experience, people construct structural spaces, such as below, on top of, inside and outside, or public space and private space, by which people then categorise events, objects and/or people.

Therefore, people we find disagreeable are described as being not close to us, while, on the other hand, our family and friends are referred to as being close. This produces some distance of the space where people are living. For instance, people categorise their homes as a private space which not everyone is permitted to enter (Jordaan 2016:96), while the park is regarded as a public space where everyone is permitted. Some spaces, such as a church or temple, are even treated as holy or sacred spaces. Therefore, some spaces cannot be penetrated by other people.

Penetration can mean 'something goes into something' or that a thing or a person moves from outside to inside of a place, or from a public to a private place (Wehmeier 2005:1076). It can also refer to the relationship between persons and gods, or the sexuality between a man and a woman (Wehmeier 2005:1076).

2.This new analysis is working together in the class with Prof Pierre Jordaan, head of the Department of Greek in the School of Ancient Language at the Northwest University, Potchefstroom Campus.
When it is used in the context of a relationship with gods, it can refer to the connection between a secular and sacred place. Similarly, when it is used in reference to relationships between people, it is associated with inward relationships, or intimacy, including sexual intercourse and outward relationships to others, or between private and public places as they relate to people. Consequently, in the book of the Susanna, there are many times where the concept of penetration is utilised.

This article, thus, will first look at grammar, focusing on 'what type of action' is used to denote movement. It will focus on the verbs of perception, such as looking, thinking, doing, charging, condemning and absolving, as well as verbs of conative modes of action in the text. Secondly, the cultural elements are looked at to explore the different ways of thinking between men and women, how God was thought of by a good person or by a person far away from him, and how God intervened in the situation of injustice.

To answer these questions, I will investigate by:

- looking at different spaces like the house, the garden, the court and heaven

- identifying verbs that would show entrance, defilement, thinking, action, condemning and absolving

- giving unique cultural background

- looking for the progressive in narrative line, typically, the spark that propels the narrative in a certain direction.

\section{Analysis \\ The house (vv. 1-13)}

The first place in the story is Joachim's house where Susanna's narrative starts. The house refers to the house of Israel as covenant people who were elected by God and are supposed to follow the law of God (Jr 31:33) (Lust, Eynikel \& Hauspie 2003:6318). This section focuses on Susanna as she goes from the house to the garden and to the court, from a private space to a public space. Joachim's family, as people of God, was established and empowered around the time of the Babylon exile (v. 1). However, the house had been penetrated by lawlessness.

\section{Babylon penetrating into the house (1-6)}

With regards to the concept of penetration, the word

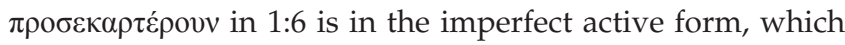
denotes continuous action in the past as an iterative mode of action (Jordaan 2013:10), followed by غ̇v, which means 'a place to spend much time in, or continually be in' (Friberg, Friberg \& Miller 2000:23 441). This verse describes that the elders, who were like a wickedness coming from Babylon (v. 5), 'were continual as a customary action in Joachim's house (v. 6)'. It gives an illustration of the manner in which these two elders, not even mentioned by name (vv. 1,5), were identified as coming from an evil place, Babylon, and the action they had done, which is that 'they were continually being in Joachim's house'. Therefore, the evil influence had defiled the house of Israel constantly. 
The elders are judges whose function was supposed to be that of protecting the people's rights (Jordaan 2009a:121; Kanonge 2009:88). They are, however, associated with wickedness inspired by Babylon (vv. 1, 5). Therefore, through these elders, wickedness already penetrated Joachim's house, illustrating that the influence of wickedness constantly penetrated into a sacred place (Israel's family) from a secular place (Babylon), or from a public place into a private place.

\section{The evil penetrating into the minds of lawlessness by sights (7-13)}

After the lawlessness unknowingly enters the house, it keeps penetrating into the minds of the two elders. The second

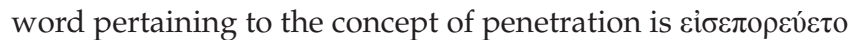
as an imperfect middle with the form of iterative mode of action, which means 'to move continuously into or to get continuously into' (Louw \& Nida 1996), emphasising the duration of an action.

This word is used twice in 1:7 and 8, respectively, and refers to moving constantly from a public place in the house into a private place (garden). Positively speaking, the word is first used to describe 'when the people left (the house) at noon,

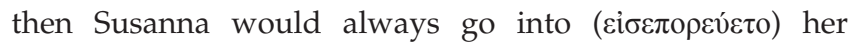
husband's garden to walk (v. 7)'.

It describes Susanna's status as the wife of Joachim, an influential person, with children. As a wife, who honours her family, and who also avoids being revealed in public, as is the proper custom, Susanna waited until people left at noon, going

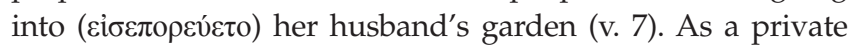
place, the garden was not supposed to have been entered (penetrated) by someone else, especially at a certain time (noon) when people left. At this stage, Susanna knows nothing about the evil thoughts of the elders, which have already grown in their hearts and will attempt to threaten her (v. 5).

Ironically, in this private place and at a certain time when it should have been empty, the two elders penetrated it by seeing (1:8: $\dot{\varepsilon} \theta \varepsilon \omega ́ \rho o v v$ [imperfect]) her entering

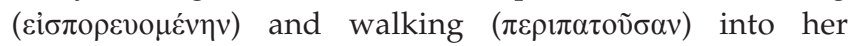
husband's garden every day (v. 7), with the result of becoming desirous for her. Because the desires they had for

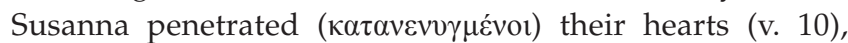



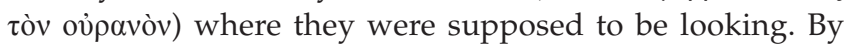
constantly peeping at Susanna, it points out a window into the mental processes of the corrupt elders because of the fact that turning one's mind away from God and hardening one's sense of shame before God's law can lead even trusted judges to become slaves to sinful desires and perjurers (DeSilva 2002:234). Because they keep watching down (the evil place) not looking up (the holy place), the elders' desire causes them to abandon righteousness.

The place of observation is significant as one analyses the story of Susanna, which represents men as those who see, and Susanna as the one who is seen. Rather, Susanna as the one who is penetrated by sight. In the subject-object relations between the genders, ${ }^{3}$ Glancy (2004:291) is correct by mentioning that 'To see is to control; to have one's vision represented is to have one's perception of the world approved'. To be seen is to be subject to control, to represent women solely as objects of others' vision denies women their subjectivity (Glancy 2004:290). Therefore, it can also be said that to be seen without knowing is being controlled, threatened or penetrated in violation. In other words, what one sees is what one thinks, and what one thinks will lead to action. Consequently, all the actions result from where one constantly looks and what one thinks of.

According to the system of honour and shame in the ancient Jewish culture, women and men have different arenas for the preservation and acquisition of honour, and different standards for honourable activity. Men occupy the public spaces, while women are generally directed towards the private spaces of house and hearth (DeSilva 2000:33). When a woman leaves the house, they are careful to avoid exposing themselves to other men or conversing with them (DeSilva 2000:33). The places they go are frequented mainly by women and so become something of an extension of private space. Therefore, to constantly watch another man's wife was not permissible, while to constantly be seen by other men was also not permissible for a wife. That is why, when Susanna was summoned to the court, she was veiled in front of the people (v. 32). However, the two elders watch another man's wife closely (penetrate), as private property, is a symbol of conventionality; while Susanna going out at a certain time into her husband's garden is a symbol of conventionality.

At this stage, the elders were not only abandoning righteousness by looking down to the evil place, but they were also lying to each other (v. 13). One of them made the suggestion to leave the house for lunch, lest he was caught out for his desire. In verse 13 , there is a subjunctive with a

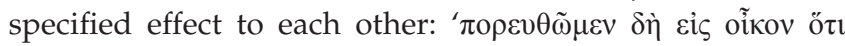

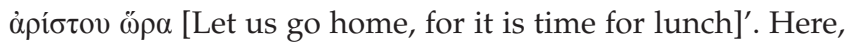
one uses his words to force the other to go home so that he might turn back secretly, but because they are equally evil, they both turn back only to be caught in the act (Coetzer 2009:354). It can be seen that their evil caused them to be hypocrites! They say one thing and do another. Finally, the evil thoughts turn into actions in the garden.

\section{The garden (vv. 14-27)}

The second place is the garden where the evil thoughts become deeds. It is also the place where Susanna confronts

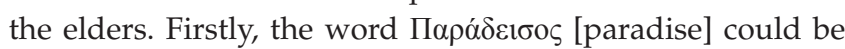
referring to a negative allusion when associated with women because it arouses Eden, which is a synonym for sin coming from Eve (Gn 2:8-3:24; Coetzer 2009:353) and resulted in her

3.Masculinity is associated with subjectivity and femininity with objectivity. In particular, man is conventionally represented as the subject of the gaze, and woman as the object of the gaze. 
becoming the prototype of all women (Kanonge 2009:99). Secondly, the garden was generally associated with sexuality in the ancient world. For instance, Persians called the garden a Paradise with the romantic name (Wright 1983:39). Thirdly, Susanna could originally be from Shoshanah in Hebrew, which could refer specifically to a lily, but is sometimes used as a generic name for flowers (Marx 2015:224). In Jewish culture, flowers in general and lilies serve as a metaphor for young women (Marx 2015:223). Shoshanah is used in the text of the beloved woman five times in the Song of Songs (2:2; 16; 4:5; 6:3; 7:3) (Marx 2015:224).

The image of Susanna in her husband's garden, which is set by fence that is a synecdoche which refers to Susanna because the singer in Song of Songs describes a husband's beloved as a sealed garden, is a typical metaphor for a young woman:

A sealed garden is my sister, my bride; a spring shut up, a fountain sealed. (Song 4:12)

The metaphor 'hedge of shoshanim' (Song 7:3) refers to a fence that is impenetrable and that no one can pass through, and the tenderness and beauty of the fence are its strength and at the same time its vulnerability (Marx 2015:244).

In the context of the text, the garden is described as being adjoined to her husband's house as an impenetrable private space. Perhaps, owing to social boundaries between men and women, moving outside is a symbol of unconventionality because the ideal was that a woman would remain concealed in the house and not show her beauty in public (Ilan 1995:128). However, taking the time into consideration, Susanna went outside only after people went away for lunch (v.7), which portrays that her movements were a symbol of conventionality and subjected to social norms.

Joachim's garden is an ambiguous space because it is both a private and a public place. In spite of the negative implication of the garden, the physical place is closely related to Susanna. However, intriguingly, the lawlessness did not come from the woman as a prototype for sin, but from the men and their lustful thoughts.

\section{Lawlessness penetrating into the garden (15-24)}

It is clear that the penetrative movement of the two elders progressed from the journey from Babylon (v. 1) to a public place (v. 6) to a private place (garden) by sight, and now turned to a deeply private place by thinking of the wife of Joachim, Susanna.

This penetration could also be progressively seen from a concrete place (house, garden) to a bodily place, breaking into a deep relationship between a couple because the fourth word for penetration is $\sigma 0 \gamma \gamma \varepsilon v \varepsilon \dot{\sigma} \sigma \theta \alpha 1$ in 1:11, which means 'to have sexual intercourse' (Liddell \& Scott). This word is in the infinitive form coming after the conative imperfect verb of $\ddot{\eta} \theta \varepsilon \lambda \mathrm{ov}$, which denotes the willingness and desire to do something continuously. This concept also occurs in 1:20 with a similar expression when the elders commanded her in the garden: 'Be with us ( $\gamma \varepsilon v o \tilde{v} \mu \varepsilon \theta$ ' $\eta \mu \tilde{\omega} \nu)^{\prime}$.

This shows that by constantly looking closely at Susanna, the ultimate intention of these two evil elders is to have sexual intercourse with Susanna. The penetration of evil progresses from sight to impure thinking and later will lead to an action. Not only did they penetrate into the house and the garden, but they also wanted to penetrate the body of Joachim's wife, which was the most sacred relationship in the family and must be protected and separated from other men because it was for begetting life (descendants). In this regard, the most important quality a man valued in a wife was fertility (Miller 2011:34-35), and the body of the wife had to be pure.

The desire turned into action, which pertains to the fourth concept of penetration, that is $\varepsilon i \sigma \tilde{\eta} \lambda \theta \dot{\varepsilon} v$, in 1:15, which means 'go into or enter (Liddell \& Scott)'. The scripture describes that 'while they (the elders) were watching for an opportune

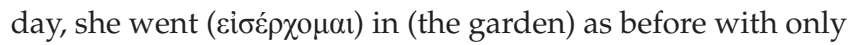
two maids, and wished to bathe in the garden (v. 15)'.

The two elders had already entered the garden, a private place, before Susanna went in because they had been hidden

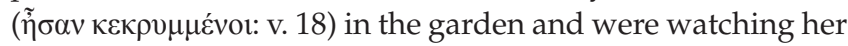

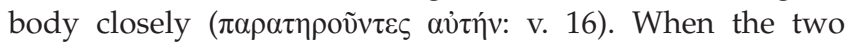
elders were giving a false witness of adultery against Susanna in court, they indirectly admitted they had already entered, and said, 'We were in the garden, and when we saw this wickedness we ran to them (v. 38)'.

At this stage, the elders found a proper time to hide in the garden and they could not stop their dangerous desires ( $\dot{\varepsilon} \pi \theta v \mu i ́ \alpha)$ on hearing Susanna's need to bathe (v. 15). Later,


and sends her maids away. This graphic description evokes the hidden elders' desires and they imagine the picture of 'a beautiful woman alone with an oily body' which puts Susanna in a vulnerable position. It propels their evil thoughts into reality. One can get an image of a naked young woman in a difficult and helpless situation without dressing, husband, helper and her maids, confessing her faith in front of two wicked elderly judges (Coetzer 2009:355). It seems a moral irony.

Here, the reality of the action begins because their desire clouded their reason, with the result that the elders command with a direct imperative in 1:20:

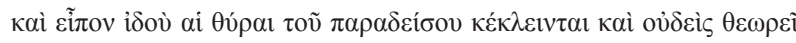

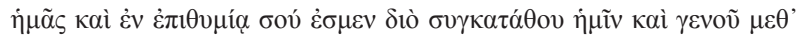
$\dot{\eta} \mu \tilde{\omega} v$ [Look, the garden doors are shut, and no one can see us. We are burning with desire for you; so give your consent, and lie with us]. (author's own translation)

However, Susanna protects the garden, her husband's property, as carefully as she protects her own body (Jordaan 2009a:118).

By closing the door, she seems secure in this private space and time. Susanna was however not precluded from the two elders, 
and it makes her powerless. By being forced to have sexual intercourse with the elders, or to be condemned of adultery, Susanna says, 'No!' to their evil intentions, to preserve her chastity as intact property for her husband's honour (Glancy 2004:291; Jordaan 2009a:124). When the garden is open to intruders, or when the wife is penetrated by the elders, the entire household is shamed and its honour lost. Nevertheless, the choice she makes preserves the integrity of Joachim's household, remaining unpenetrated by any other men.

Through the usage of these words, with reference to the concept of penetration, the lawlessness from Babylon had gradually infiltrated from the outside sphere into the inside of the house and from a public place into a private place.

\section{The lawlessness exposing the private space (25-27)}

Because of her refusal, it comes to another word with the concept of penetration ( $\eta v 01 \xi \varepsilon v$ ) in $1: 25$, which literally means 'to open' but can also mean 'to give entrance or access to' (Friberg, Friberg \& Miller 2000:2183). Not having his desires satisfied, one of the elders opens the door to the garden, which is supposed to be a private space, and gives entrance for all the people to penetrate into the private space to see what had happened in the inner place of the house.

In the ancient Jewish culture, all the authority belonged to the husband who was the master of the household and manager of all property. However, firstly, the elders penetrate the authority of Joachim and act as the master, taking over the position of Joachim to open the door of a private space. Secondly, they penetrate the garden, transforming it from a private space to a public space because 'they (people) rushed in ( door to see ...' (v. 26). Now, not only the elders saw Susanna but also the crowd, who saw and were defiled by the false witness. The evil filled the house and also all the Jewish community. It leads the elders to hold court by misusing their authority.

\section{The court (vv. 28-64)}

The third place is the court which exists wherever the judges are. In the text, the court was held in Joachim's house because 'these men (the judges) were frequently at Joachim's house, and all who had a case to be tried came to them there' (v. 6). The judge is 'the one who makes decisions based on examination and evaluation judge, used of both divine and human judges' (Friberg, Friberg \& Miller 2000:16702).

In the Old Testament, God himself is judge and is both legislator and legal partner, watching over the relationships of the people and acting on their behalf against their enemies and those who are evildoers (Theological Dictionary of the New Testament 470). God's judgement manifests his lordship and gives it an ethical orientation towards his people. All the legal enactments expound the basic decision: 'I will be your
God, and you shall be my people'. Therefore, the court must proclaim God's mercy, as well as justice (Dt 10:18). The court in Joachim's house was supposed to be just and righteous, convicting the elders of perjury, as the extent of their transgression is implied, but sadly the court never heard an account of the truth and what actually transpired (Glancy 2004:301). The reason is that the judges were defiled by evil, penetrating into the court. Lastly, the crowd does not gather to serve justice, but to serve the two evil judges.

\section{Lawlessness penetrating the court (28-31)}


the elders held the court in the house of Joachim and summoned Susanna in front of all the people in order to give a false witness against her which would sentence her to death (vv. 28-29).

Culturally speaking, Susanna, as a wife, was the property of Joachim and was not allowed to be presented in a public space because women belonged to the privacy of the house. If women appeared in public in front of people, especially in a formal place, they were covered up by veils (Gn 38:15). In the text, however, before giving the accusation of adultery against Susanna, the elders penetrated her by ordering her to be

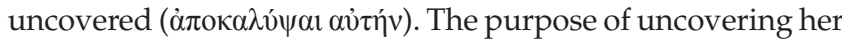
(as Joachim's wife) in public is very terrible, which is that 'they [all the people] might be filled with her beauty (ö $\pi \omega \varsigma$

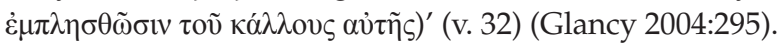

Thus, with this purpose, the elders are continuous and thorough in their wicked action of gazing at Susanna. In this evil, improper way one can see that the evil influence has caused all the people to sin by looking at Susanna. Not only did the two elders penetrate Susanna but also all the people together penetrated her by looking at her. Lastly, the court is a place where there should be justice, but it was penetrated and defiled by lawlessness.

\section{Lawlessness penetrating into the body of Susanna}

After causing all the people to look at (penetrate) Susanna, the elders had not yet finished their evil plot of penetration. They go even further by penetrating the body of Susanna by placing ( $(\bullet \eta \uparrow \alpha v)$ their wicked hands on her head (v. 34).

The original verb of the word $\ddot{\varepsilon} \theta \eta \kappa \alpha v$ is $\tau i \theta \eta \mu$, which literally means 'to place or to lay'. This word has the same meaning as in secular Greek which is 'setting down, erecting, placing, investing, putting on, also setting snares, hazarding one's life, taking to heart, appointing, issuing (orders)' (TDNT:1178). In the legal case of Susanna, the word can be connected to the negative concept of 'setting snare of her life' or 'hazarding her life' by demanding the death penalty on Susanna in court.

In the LXX, when using the word ti $\theta \eta \mu \mathrm{l}$, it refers to God as the subject in his work of creating, saving and judging (TDNT:1178), for God saw that it was good (Gn 1:17-18). As judges of God in the court, the elders were supposed to be just and under the 
authority of God. However, in the text, the elders placed their hands on Susanna's head with wicked thoughts and injustice and not according to the covenantal commandment in the law of God, who is the true Judge. Even though Susanna turned her eyes to heaven in front of them with the purpose of reminding and challenging them to turn back to heaven, the elders continuously looked down at Susanna (Glancy 2004:295). Thus, Susanna was sentenced to death.

In this regard, the elders, representatives of Babylon, not only penetrate the domain of the earth but also want to take over (penetrate) the authority of God. By replacing God's position, the elders played God to defile all the people of God in the court. Therefore, not only does lawlessness penetrate Susanna by touching her body but they also penetrate the place and authority of God to put the innocent, Susanna, to death.

All in all, the progression of the penetration of evil on earth can be fully illustrated by the comprehensive Figure 1 .

From Figure 1, one can see that the penetrating of the wicked

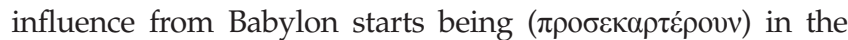
house, when the elders are looking closely ( $\dot{\varepsilon} \theta \varepsilon \omega \dot{\rho} \rho o v v)$ at

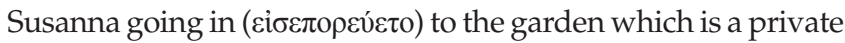
place in the house, and leads to evil thoughts penetrating

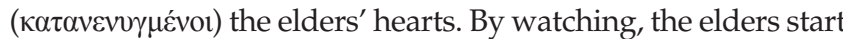

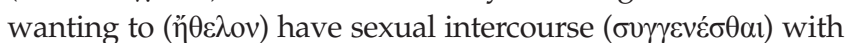
Susanna. This brings them to take action by going into ( $\varepsilon i \sigma \tilde{\eta} \lambda \theta \dot{\varepsilon} v$ )

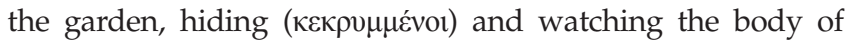
Susanna closely ( $\pi \alpha \rho \alpha \tau \eta \rho \tilde{v} \tau \varepsilon \varsigma$ ) to find a good time when Susanna was alone and by forcing her to concede to their evil intentions. Because of Susanna's refusal, the penetration progresses to the opening (invor $\xi \varepsilon v$ ) of the door of the garden (private space) and even calling all the people to rush into ( $\varepsilon i \sigma \varepsilon \pi \eta ́ \delta \eta \sigma \alpha v)$ the garden to see. Lastly, the penetration continues


face to the public and touching ( $\left.\ddot{\varepsilon}^{\prime} \theta \eta \kappa \alpha v\right)$ her head with evil hands. Here, lawlessness penetrates ( $(\varepsilon \eta \eta \kappa \alpha v)$ the authority and place of God, who is the real Judge. Therefore, the entire bottom domain on earth from the house to the garden and the court has been defiled by the wicked power of Babylon through the elders (judges), and Susanna was sentenced to death.

What can she do? The only thing she can do is to cry out and

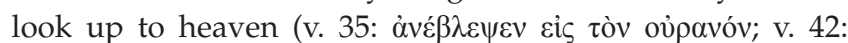

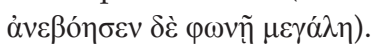

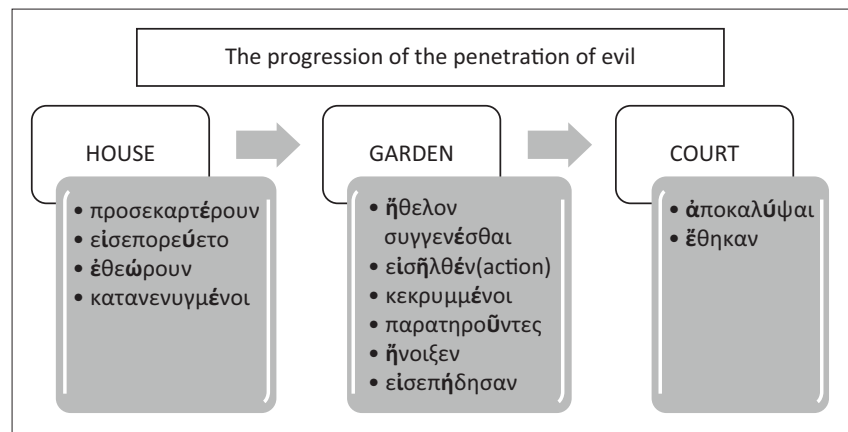

FIGURE 1: The progression of the penetration of evil.

\section{Heaven}

Heaven is a place symbolising God. It is the direct opposite of Babylon and inspires an ideology opposite to Babylon's. These different directions point out where people's hearts are in the story of Susanna. Heaven is a place which the elders avoid constantly, but for Susanna it is the place where her help comes from and the place where she looks up to (vv. 35, 42) (Kanonge 2009:97). In contrast to Susanna, the elders turn their eyes from heaven to the earth (v. 9). Therefore, the elders belong to Babylon, which inspires wickedness to defile the places and people on the earth, whereas Susanna belongs to heaven which inspires the Holy Spirit (v. 45) to conquer evil.

This is in contrast with Babylon which does not only symbolise the setting (v. 1) but also has an ideological connotation that refers to one of the terror images of the Bible. The text says that 'Wickedness came forth from Babylon (v. 5)'. One of the characteristics of Babylon is that it is a world power, which is hostile to God and denounced by the prophets in the Bible (Bauer et al. 2000:1385; DeSilva 2002:234). Because the king of Babylon, Nebuchadnezzar, destroyed Jerusalem and exiled many of the Israelites, it was regarded as a kingdom of wickedness against God and his people (Porter 2013:35). Therefore, in the story of Susanna, Babylon also symbolises a place which is filled with a proud power of oppression, wealth, luxury, sexual license and idolatry (Kanonge 2009:96). This is illustrated by the two elders, who are directly opposed to God, penetrating into the bottom domains of the house, the garden and the court of God's people to play God. In this evil situation, Susanna confronts the unrighteous judgement which sentenced her to death by crying out and looking up to heaven, which denotes another unchartered space.

\section{Susanna looking up to heaven}

Being sentenced to death, there is no one in the whole story that supports Susanna. In court, her father, Hilkiah, and her husband, Joachim, are absent. They say nothing, not even to ask questions. Therefore, where will Susanna's hope come from?

The only hope for her is to ask for help from heaven. The idea of asking for help from heaven runs through the entire narrative. When Susanna encounters the false judgement in the garden, the first thing she does is to cry up (to heaven) with a loud voice (v. 24: $\alpha v \varepsilon \beta o ́ \eta \sigma \varepsilon v ~ \varphi \omega v \tilde{n} \mu \varepsilon \gamma \alpha \dot{\lambda} \lambda \eta)$ for help; yet,

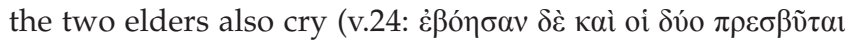
$\kappa \alpha \tau \dot{\varepsilon} v \alpha v \tau \imath \alpha v i \tilde{\varsigma} \varsigma)$ to make a false witness against her. When the two elders place their evil hands on her head to charge her, Susanna again cries and looks up to heaven, for her

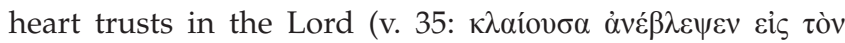

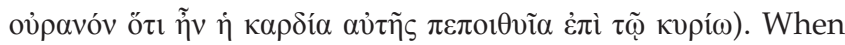
she is about to die, she still cries up with a loud voice (v. 42: $\dot{\alpha} v \varepsilon \beta \delta ́ \eta \sigma \varepsilon v \delta \dot{\varepsilon} \varphi \omega v \eta ̣ \tilde{~} \mu \varepsilon \gamma \alpha \dot{\alpha} \lambda \eta$ ). In contrast to the actions of the lustful and evil judges, Susanna acted according to the law of God and represented a person who looks up to heaven 
in fear of the Lord. It refers to the wisdom tradition of Israel that fear of the Lord and remaining loyal to God's commandments are foundational values, despite the temporal dangers, such as death (DeSilva 2002:234; see 2 Mac. 6:26). As the wife of Joachim, being intact property, Susanna's choice preserves the real integrity of Joachim's household; she remains unpenetrated by any other men (Glancy 2004:295) because she belongs to heaven.

Susanna does not only look up to the heaven for help when she is persecuted but also knows of God's sovereignty. Her prayer expresses confidence in God's knowledge of what is hidden beneath deceptive conspiracies: 'ó $\tau \tilde{\omega} v \kappa \rho v \pi \tau \tilde{\omega} v$

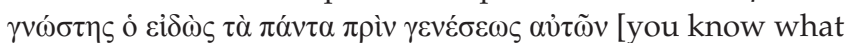
is secret and are aware of all things before they come to be]' (v. 42). This can be seen clearly when Susanna refused to have sexual intercourse with the elders because she knew that even though there was no one in the garden, God was still

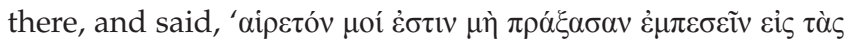


will fall into your hands, rather than sin in the sight of the Lord]' (v. 23).

This theme is well established in the Hebrew Scriptures (1 Sm 16:17; Dn 2:22; Jdt 9:5-6). The knowledge of the omniscient God confirms the conviction that God is absolutely just and would not permit injustice to have the last word in human affairs (DeSilva 2002:235). God justifies those who walk uprightly and brings the sinner and oppressor to punishment. In the story of Susanna, it can be seen that God not only cares for his people as a whole but also intervenes on behalf of the individual (Moore 1977:28).

In the text, Susanna is described by Daniel as a daughter of Judas in 1:57: 'This is how you have been treating the daughters of Israel, and they were intimate with you through fear; but a daughter of Judah would not tolerate your wickedness'. This verse shows that the daughters of Israel who previously submitted to the elders did so out of fear. This untold story, embedded in the fuller narrative, emphasises the elders as men who achieve their sexual ends, not by playing on seduction, but by exploiting fear (Glancy 2004:299). It hints at the difference between the daughters of Israel and the daughters of Judah. The former fear people, threat and death; the latter fear the Lord despite persecution or death and would rather die than commit sin against God.

The expression of daughters of Israel (v. 48) is intended to give credit to Susanna as a legitimate member of the community on the basis of genealogy (Kanonge 2009:84). The daughter of Judah (v. 57) is related to Susanna's practice of the law. This name is linked to the religious aspect of the Jewish community in the Second Temple period (Kanonge 2009:85). Here, Susanna is characterised not only as a member of the community by genealogy but also as a woman who fears the Lord because she looks to heaven, a place which belongs to God. Even though the trial in the court itself is far from a model of justice, God works in Daniel by divine inspiration against the wicked judges (DeSilva 2002:232).

\section{God intervenes by Holy Spirit}

At the trial, Susanna's cry up to heaven prompts God to stir the holy spirit of Daniel to be her defence and attack (Jordaan 2009b:45). Ironically speaking, God uses a young man who was used by the elders as a fictitious figure to stand against themselves, but Daniel was not aroused sexually as the elders were (Coetzer 2009:359). He was a young man whose spirit had been aroused by God to protect this helpless and innocent woman by asking questions in order to re-examine the truth.

Now, Daniel separates the two elders and asks them a crucial question. Because of the different statement given by the accused under examination, Daniel had convicted them of bearing false witness. Lastly, the crowd stands against the unjust judges (the elders), and acting in accordance with the Law of Moses they put them to death. Interestingly enough, in the process of the entire trail, Susanna's father, Hilkiah, and husband, Joachim, who were supposed to help her, did nothing. Susanna was always alone until God aroused the spirit of Daniel.

Even though Daniel acts as a liberator in the court, Susanna is actually indirectly the agent of her own deliverance. Daniel

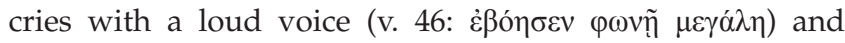
reopens the judgement, which results from Susanna's first cries to heaven (vv. 24, 35, 42). Because of this, the whole

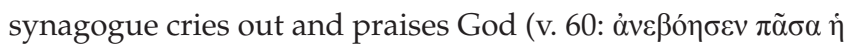

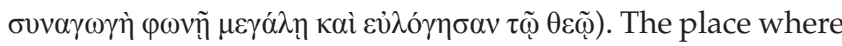
Susanna cries out and prays is an illustrative manifestation of piety which shapes the direction of the plot. Only at this moment does God inspire Daniel to help (Glancy 2004:302). The story never shows that Daniel looks at Susanna, but God actually looks at Susanna through the Holy Spirit who acts through Daniel and restores her reputation as an upright wife (Glancy 2004:296). By the inspiration of the Holy Spirit of God, Daniel controls the gaze of the story through testifying that the elders' vision is false. Finally, justice has returned to the people of God. All of this happens as a direct result of the power of heaven, which is not able to be defiled. All in all, the progression of the penetration of evil on earth and the help from heaven can be fully illustrated by the comprehensive Figure 2.

\section{Conclusion}

From Figure 2, it is clear that the different physical spaces of the bottom, or earth, and help from the non-physical heaven above have never been explored in this way. In the different spaces on earth, it shows that the penetration of evil power is progressive from the house, the garden and the court to the opposite relationship between goodness and lawlessness. In this process of movement, it keeps tension between the power of the down, Babylon, and the power of the up, heaven. Even though all the spaces are defiled by evil, the space of heaven, which belongs to God, is not able to be defiled because God's eye sees a panorama of the cosmos, his face is everywhere and he rules both the down and up. By inspiring the spirit of a young man, the Holy Spirit becomes 


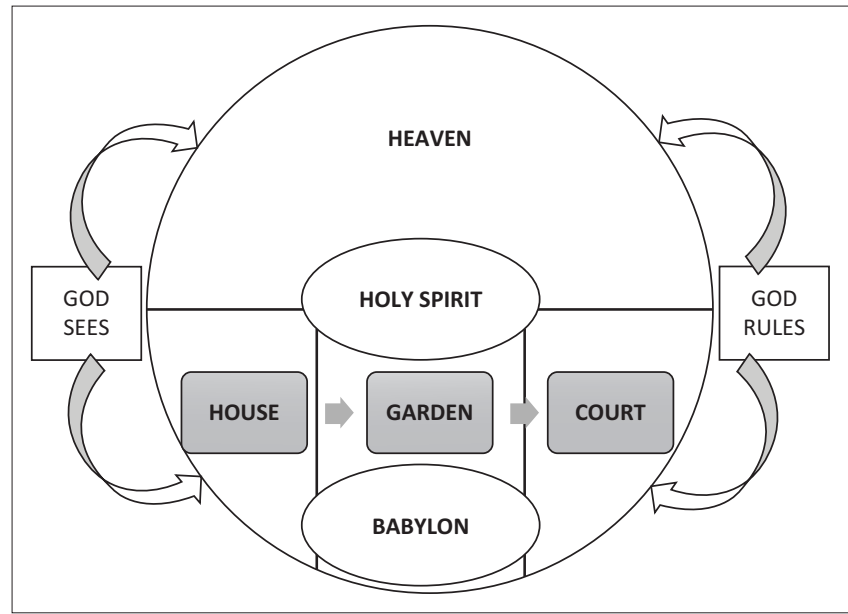

FIGURE 2: The worldview of the Theodotian Susanna.

the bridge between the space of up and the space of down. Therefore, all the people should praise God, who saves those

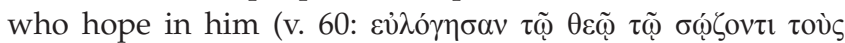

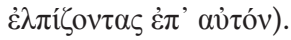

\section{Acknowledgements Competing interests}

The authors declare that they have no financial or personal relationships that may have inappropriately influenced them in writing this article.

\section{Authors' contributions}

It emerged from P.J.J. 's previous research on Theodotian Susanna. C.W.C. wrote the article and P.J.J. made corrections to the various draft versions of this article.

\section{References}

Bauer, W., Arndt, W.F., Gingrich, F.W. \& Danker, F.W., 2000, A Greek-English Lexicon of the New Testament and other early Christian Literature, The University of Chicago Press, Chigaco and London.

Branch, B.G. \& Jordaan, P.J., 2009, 'The significance of secondary characters in Susanna, Judith, and the additions ot Esther in the Septuagint', Acta Patristica et Byzantina, 389-416.
Coetzer, E., 2009, 'Performing Susanna: Speech acts and other performative elements in Susanna', in J. Cook (ed.), Septuagint and reception: Essays prepared for the Association for the Study the Septuagint in South Africa, pp. 347-360, North-West Association for the Study the

DeSilva, D.A., 2000, Honor, patronage, kinship \& purity: Unlocking New Testament culture, InterVarsity Press, Downers Grove.

DeSilva, D.A., 2002, Introduction the Apocrypha: Message, context, and significance, Baker Academic, MI.

Friberg, B., Friberg, T. \& Miller, N.F., 2000, Analytical Lexicon of the Greek New Testament, Baker, Grand Rapids, MI.

Glancy, J.A., 2004, 'The accused: Susanna and her readers', in A. Brenner (ed.), A feminist companion to Esther, Judith and Susanna, pp. 288-302, T\&T Clark International, New York.

Gruen, E.S., 2002, Diaspora: Jews amidst Greeks and Romans, Harvard University Press, Cambridge, MA, London.

Harrington, D.J., 1999, Invitation to the Apocrypha, Willian B. Eerdmans Publishing, Grand Rapids, MI, Cambridge.

Ilan, T., 1995, Jewish women in the Greco-Roman period, Hendrickson Publishers, Peabody.

Jordaan, G.J.C., 2013, Ancient Greek inside out: The semantics of grammatical constructions, LIT Verlag, Berlin.

Jordaan, P.J., 2009a, 'Reading Susanna as therapeutic narrative', Journal for Semitics $17(1), 114-128$.

Jordaan, P.J., 2009b, 'Daniel as weapon for attack and defense through the ages', Ekklesiastikos Pharos (90), 45-53.

Jordaan, P.J., 2013, 'Body, space and narrative in 2Macc 1:1-10a', Biblical Notes 168 90-102.

Kannonge, D.M. 2009, The emergence of women in the LXX apocrypha, a semiotic study of Susanna, North-West University, Potchefstroom.

Kay, D.M., 2004, 'Susanna', The Apocrypha and Pseudepigrapha of the Old Testament $1,638-651$.

Kottsieper, I., 1998, Das Buch Baruch Der Brief des Jeremia Zusatze zu Ester und Daniel, Vandenhoeck \& Ruprecht, Gottingen.

Lakoff, G. \& Johnson, M., 1999, Philosophy in the flesh. The embodied mind and its challenge to Western thought, Basic Books, New York.

Louw, J.P. \& Nida, E.A., 1996, Greek-English Lexicon of the New Testament based on sematic domains, vol. 1 and 2, 2nd electronic edn., United Bible Societies, New York.

Lust, J., Eynikel, E. \& Hauspie, K., 2003, Greek-English Lexicon of the Septuagint, Deutsche Bibelgesellschaft, Stuttgart.

Marx, D., 2015, 'Ancient Jewish prayers and emotions', Deuterocanonical and Cognate Literature Studies 26, 221-237.

Miller, G.D., 2011, Marriage in the book of Tobit, De Gruyter, New York.

Moore, C.A., 1977, Daniel, Esther, and Jeremiah, Doubleday, New York.

Moore, C.A., 1984, Daneil, Esther, and Jeremiah: the Addtions, Doubleday, New York. Nickelsburg, G.W.E., 2005, Jewish literature between the Bible and the Mishnah: $A$ historical and literary introduction, Fortress Press, Minneapolis, MN.

Nolte, S.P. \& Jordaan, P.J., 2010, 'Susanna: A story of dangerous spaces', Journal for Semitics 19(2), 507-527.

Porter, S.E., 2013, 'What can we learn about grammar and from a Mosaic?', in The language of the New Testament: Context, history, and development, vol. 3, Brill, Leiden and Boston, MA.

Wehmeier, S., 2005, Oxford advanced learner's Dictionary, Oxford University Press, New York.

Wright, R., 1983, The history gardening, Garden City Publication Company, New York. 